African Journal of Law, Political Research and Administration

ISSN: 2689-5102

Volume 4, Issue 1, 2021 (pp. 85-101)

www.abjournals.org

\title{
OIL THEFT: DEREGULATION OR CONTRACTING SECURITY TO MILITANTS?
}

\section{C.O. Okwelum (Ph.D)}

Delta State Polytechnic, Ozoro. Tel: 08075684274

Cite this article:

C.O. Okwelum (2021), Oil

Theft: Deregulation or

Contracting Security to

Militants?. African Journal of

Law, Political Research and

Administration 4(1), 85-101.

DOI: $10.52589 / A J L P R A-$

9NFKDEZQ.

\section{Manuscript History}

Received: 12 April 2021

Accepted: 30 April 2021

Published: 25 May 2021

Copyright $\odot 2020$ The Author(s).

This is an Open Access article distributed under the terms of

Creative Commons Attribution-

NonCommercial-NoDerivatives

4.0 International (CC BY-NC-ND

4.0 ), which permits anyone to

share, use, reproduce and

redistribute in any medium,

provided the original author and

source are credited.
ABSTRACT: Oil theft in the Niger Delta, where the Nigerian economy derives its mainstay, has now acquired the front burner in oil and gas scholarly discourse because of the alarming regularity of the scourge. Several perspectives have emerged in the narratives particularly in the ideological spectrum, but there appears to be conflicting policies directed toward combating the challenge of theft. This paper, which adopts the doctrinal research methodology, examines the twin issues of deregulation and security for the critical assets-the oil installations and pipeline facilities. While government investigation panels, that have critically studied the problems, have advised for deregulation, the State appears to be treading the opposite line of retaining the commanding heights and engaging militants and natives in securing the assets. This approach has not encouraged private initiatives and indigenous technology transfer but has put the State on the defensive and therefore requires shift.

KEYWORDS: Niger Delta, Oil Theft, Deregulation, Security Contract and Policy. 


\section{INTRODUCTION}

The Brass-Akassa corridor on the Atlantic fringe has been identified as a notorious spot for crude oil theft by security operatives. ${ }^{1}$ To Akinosho Toyin, the flawed implementation of the amnesty programme of the Federal government is the cause of oil theft in the Niger Delta, arguing that the theft began in 2001 and morphed into militarization with kidnapping. The poor workability of the amnesty programme has now ushered in vandalism again and theft, and 'when you are giving a thief a job, it does not send the right signal out; it encourages brigandage. ${ }^{2}$ Yet the trio of Amaize, Oyadonga and Onoyume ${ }^{3}$ consider Nigeria to be in dire straits. Having been reporting on the oil industry sector over the years, they have acquired a certain high degree of authority and the result of their investigative journalism is that very highly placed individuals are involved in the conspiracy involving high technology crime, with well-built cartels responsible for oil theft in Nigeria.

In their analysis, the cartels are highly connected people in and outside government and oil companies, businessmen, retired and serving military officers including people you may never have thought could be involved in bleeding the country dry. Those who steal crude oil from well heads with cotonou boats and then hide in the bush in the creeks to refine and sell to petrol station owners are a group. They are in the kindergarten section of the business. The main culprits are the unseen ones. They do not go to the pipelines to hack and steal crude oil. They do their transactions at the various oil terminals. Whether at Forcados or Bonny, officials can declare that only two vessels were loaded when ten were loaded. They ask, 'do you think anybody will be complaining about the stealing of crude oil if it is just the volume that villagers steal and refine to make a living?'

\section{Military Complicities}

Oil cartels have illegal points where they siphon oil through long hoses into their waiting boats, with the cooperation of military officials. For instance, in July 2013, the Joint Military Task Force (JTF) discovered three illegal crude oil loading points, one each at Igbomotoru, Oyeregbene and Mbikiba, and urged Agip to carry out an assessment on the illegal loading points before having them sealed up. ${ }^{4}$ 'The poor class who were doing the business to earn a living have long quit the business because of the manhunt by security agents, who destroy their properties as they could not afford huge amounts to settle the agents on a daily or monthly bases as the cases may be,' the trio of Amaize, Oyadonga and Onoyume report. ${ }^{5}$

\footnotetext{
${ }^{1}$ Oyadongha Samuel, Grounded crude oil barge: Navy arrests tug boat, 6 suspects. www.vanguardngr.com. August 15, 2013.

${ }^{2}$ Akinosho Toyin, The News Interview: Flawed Implementation of Amnesty Programme caused oil theft in the Niger Delta. http://mobile.saharareporters.com. April 15, 2013.

${ }^{3}$ Akinosho Toyin, The News Interview: Flawed Implementation of Amnesty Programme caused oil theft in the Niger Delta. http://mobile.saharareporters.com. April 15, 2013.

${ }^{4}$ Asu Femi, JTF discovers illegal crude loading points, impound barges. http://businessdayonline.com. July 4, 2013.

${ }^{5}$ Amaize Emma, Oyadonga Sam and Onoyume Jimitota, Oil: The conspiracy that robs Nigeria of billions of dollars. www.vanguardngr.com. August 25, 2013.
} 
ISSN: 2689-5102

Volume 4, Issue 1, 2021 (pp. 85-101)

Military men see the business as a money-making venture. They lobby to be posted to the Niger Delta creeks in order to make illicit fortunes to buy expensive cars and build large houses. Oil men lobby military men in oil installations to enable them to load raw crude from points and to refine paying N100,000 to N200,000 per boat; local refinery operators settle military men in their operational areas with N1 million to N2 million per week. Most military men, government officials and oil company workers have big vessels, cotonou boats, barges, local refinery ports and illegal points allocated to individuals to steal oil and make huge amounts of money. They are selective in their operations; they only go after people who refuse to settle them. ${ }^{6}$

Oil theft in Nigeria is a huge criminal operation affecting companies and states around the world. It is a genre of organized crime that is almost totally off the international communities' radar. Without better knowledge of how the stolen oil trade works, not every government can ignore it with confidence. Unfortunately, interest in tackling the problem is low. The quantity stolen is disputed according to Chatham House. ${ }^{7}$ Varying from 150,000 bpd and above, and costing $\$ 6$ billion annually, proceeds are laundered through world financial centers and used to buy assets in and outside Nigeria. To Chatham House, politicians, military officers, militants, oil industry personnel, oil traders and communities profit from the industrial theft. It is not only being stolen from pipelines but from tank farms, export terminals, refinery storage tanks, jetties, ports and wellheads. ${ }^{8}$

However, oil theft manifests in three ways: Firstly, the ordinary people who cut the pipes, put it in jerry cans, and go and heat it in some form of illegal and/or artisanal refineries. This group is prevalent in the Niger Delta. Secondly, the group which puts the crude oil in barges and sells it. Thirdly, the group which is stationed with big vessels in the high sea and sells it abroad. ${ }^{9}$

Cracking down on those involved could inflame tensions amongst powerful figures in the southern oil-producing Niger Delta region, where unrest declined after the 2009 amnesty proclamation on rebels, but stability remains elusive. Companies have in recent times sold onshore assets seemingly to focus on deep-water projects where the risks of theft and unrest are limited. The initial stages of Nigerian crude theft are largely known, with gangs tapping into pipelines and pumping crude to smaller vessels which take it to larger ships and barges for international sale. Chatham House believes it is less clear where the illicit crude is taken abroad and how it gets there. It partly reaches world markets through 'co-loading' where stolen oil is put on ships carrying legal oil. Documents are forged and the vessel departs seemingly laden with legitimate cargo. ${ }^{10}$

\section{Chatham House Findings}

Chatham House's investigation-which was based on interviews of over 200 governments, private sectors and independent sources, and reviews of thousands of documents - concluded that the USA may not be the leading destination for illicit cargo because US refineries more rigorously inspect incoming crude cargo. Refineries in regional markets like Cameroon, Ghana

\footnotetext{
${ }^{6}$ Id.

${ }^{7}$ Lagos (AFP), Nigerian crude oil stolen on an industrial scale. www.vanguardngr.com. September 20, 2013.

${ }^{8}$ John Vidal, F1bn a month: The spiraling cost of oil theft in Nigeria. www.theguardian.com. October 5, 2013.

${ }^{9}$ Ahamefula Ogbu, Nigeria: Oil theft - We are yet to catch the big thieves, says Mittee. http://m.allafrica.com/stories. October 14, 2013.

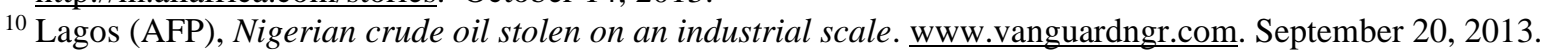


ISSN: 2689-5102

Volume 4, Issue 1, 2021 (pp. 85-101)

and Ivory Coast are listed as likely buyers and collaborators. Refineries in China, India, Singapore and Eastern Europe all purchase stolen Nigerian oil but the think tank found little direct evidence in support of any specific charge. ${ }^{11}$

According to the London-based research group, oil is being stolen on an industrial scale and Nigeria's politicians and security officials are profiting; many have attributed the major cause of crude oil theft to pipeline vandalism but the problem is more than pipeline vandalism as substantiated by the Ribadu Committee. According to Felix Ayanruoh, ${ }^{12}$ not much that is serious is heard about the real cause of oil theft or what stakeholders in the industry are doing to stem the scourge because crude theft involves a convoluted and complex web of relationships spanning all levels of the society. These relationships are alleged to include highly connected people in and outside government (members of the executive and legislature), oil companies (including the NNPC), businessmen, retired and serving military officers, and militants, among others. ${ }^{13}$

\section{Oil Company Complicity: A Shell Example}

The complicity of Shell and the military in the Trans Niger Oil Pipeline thefts, for instance, can be borne out by the statements of the Official Observer for the Bodo investigation. ${ }^{14}$ Reverend Father Obi stated: 'I am personally sure that Shell knew that its oil was being stolen. If Managers did not know, then those they put in charge seemed to know. This theft could not have happened without the collusion of the authorities and the military. If they do not publish their report, I publish mine.' The Catholic Reverend Father queried: 'Why was a massive barge able to hold 10,000 barrels of oil being loaded at 2 am with crude? Why were local observers arrested the next day? Why were their cameras confiscated and memory cards destroyed? Were the thieves not being protected by the military?'

However, if there is any multinational that is alive to its publics yet most criticized, it is Shell. Shell's level of response to the Bodo explosion and its plight generally in the Niger Delta is not only admirable but forthright. Mutiu Sunmonu and Phillip Mshelbila ${ }^{15}$ of Shell stated: 'Unknown persons continued to reconnect illegal bunkering hoses at Bodo West even as our pipeline team was removing crude theft points.' 'One has to understand that there is this accusation that the oil industry employees are behind this, but there are thousands of people who have the skills who may have been working with the industry over the years. These people are outside and some of them may be for hire.' And 'The success of any interim measure and final remediation depends on the cessation of oil theft and illegal refining in the area which reimpacts the environment and remains the cause of most oil pollution in the Niger Delta.' ${ }^{16}$ The Bodo explosion was significant in that it showed how that oil theft in Nigeria had reached an industrial scale and ranks with the drugs trade as the most lucrative crime in the world. ${ }^{17}$

\footnotetext{
${ }^{11} \mathrm{Id}$

${ }^{12}$ Id. See also, Chatham House, Nigeria oil theft a global criminal enterprise. http://pmnewsnigeria.com. September 19, 2013.

${ }^{13}$ Ayanruoh Felix, Nigeria - Cold facts of crude oil theft. www.vanguardngr.com. October 15, 2013.

${ }^{14}$ John Vidal, F1bn a month: The spiraling cost of oil theft in Nigeria. www.theguardian.com. October 5, 2013.

$15 \mathrm{Id}$

${ }^{16}$ John Vidal, Niger Delta oil spill victims reject 'derisory' Shell compensation offer. www.theguradian.com . September 13, 2013.

${ }^{17}$ John Vidal, F1bn a month: The spiraling cost of oil theft in Nigeria. www.theguardian.com. October 5, 2013.
} 
But Asobie ${ }^{18}$ had a point against the benign disposition of Shell to its publics in the face of its plight in the Niger Delta business environment. He argued that the multinationals are not just oil companies, they are joint venture companies, which means that they are in collaboration with the indigenous people - masters in politics, military officers, foreigners and militantswho steal. In other words, the sophistication of Shell in explaining its predicament to its publics should be taken with a pinch of salt as a distinction ought to be made between the ordinary vandals who roughly break the pipelines out of need, frustration and desperation, and the oil companies which steal sophisticatedly. For instance, Asobie canvassed that it is true that there is sophisticated oil stealing: 'I think what happens is that when it comes to lifting, when they are not properly supervised, they give figures of what they have lifted, which is often not as good as what is actually lifted.' 19 Furthermore, officials and private actors disguise theft through manipulation of meters and shipping documents. ${ }^{20}$

There is a certain high degree and level of synergy and complicity between those who are supposed to check oil theft and those perpetrating it, and this relationship is being underrated. One of John Vidal's findings (through an interviewee) is that: 'A lot of big-time stealing goes on. You know the oil you are offered is stolen. They give it to you without documents, at a cheaper rate. I was offered 50,000 liters for N55 a liter instead of N75 government rate. There is no chance getting caught because there is no system to catch people. Big business is big politics.' Vidal submits that the Nigerian military has become deeply implicated in oil theft since the amnesty proclamation and the military, instead of the militants, now controls the oil platforms. Thieves now have to buy oil directly from the military, which is a chain of command. It is far easier to go straight to the military. ${ }^{21}$

Under interview, Mittee Ledum ${ }^{22}$ asserted further that 'You need to see how big some of these barges are and they move from here to the sea, and if you want to transport yourself from here to that place, you know how many security checkpoints you are going to pass through there and then you find that not much is happening in those areas. Our law enforcement is clearly compromised.' 'Our law enforcement dragnet has not been able to catch the fishes, because in a system like ours, if you go fishing and you lay your nets, when big fishes come, they tear the net and pass, but you can catch the smaller ones. So, we need to enforce a system that will ensure that whoever is involved will be caught.'

\section{The Wihbey, Boyloaf and Asobie Theses}

Paul Michael Wihbey ${ }^{23}$ described oil theft or bunkering as an economic insurgency which spreads across the world, with criminal gangs on ground to smuggle the product into other economies without payment of necessary duties. If local authorities cannot collect taxes on illicit oil, Nigeria puts itself at risk of potential sanction and quarantine of its crude oil export products. Wihbey argued that the surge in oil theft could be linked to the fatal error of non-

\footnotetext{
${ }^{18}$ Olayinka Collins, Nigeria is oil-dependent, not oil-rich, says Asobie. www.ngrguardiannews. October 16, 2013.

${ }^{19} \mathrm{Id}$

${ }^{20} \mathrm{Id}$

${ }^{21} \mathrm{Id}$

${ }^{22}$ Ahamefula Ogbu, Nigeria: Oil theft - We are yet to catch the big thieves, says Mittee. http://m.allafrica.com/stories. October 14, 2013.

${ }_{23}$ Ebiri Kevin, How bunkering puts Nigeria's oil export in jeopardy. www.ngrguardiannews. September 29, 2013.
} 
ISSN: 2689-5102

Volume 4, Issue 1, 2021 (pp. 85-101)

passage of the 2011 version of the Petroleum Industry Bill. It recommended 10 percent equity stake for host communities in the Niger Delta. He believed that oil theft cannot be resolved through security means (JTF) as long as oil-producing communities continue to wallow in abject poverty. ${ }^{24}$

Wihbey's position is almost in tandem with that of Ebikabowei Victor Ben (Boyloaf) ${ }^{25}$ who argued that oil theft in the Niger Delta will not stop until the Federal Government takes appropriate steps to compensate the various natives of the region. This is because the owners of the land where the oil facilities crisscross do not feel any sense of belonging after many decades of oil production. Ebikabowei, a well acknowledged militant, stated: 'I hate to hear the word "oil thieves or oil theft" because the people you want to label as thieves are simply trying to make use of their God-given resource.' In other words, what they are doing is the legitimate 'resource control.' Nigeria is oil-dependent, not oil-rich. Boyloaf's thesis was further amplified by Assisi Asobie ${ }^{26}$ that more importantly, the people of the Niger Delta are stealing oil because they realize that stealing is going on at the highest level of government, not only of oil but oil money. They regard oil theft as informal tax; they do not look at it as stealing.

But Boyloaf's thesis does not bode well in law. Not only is it an act of robbery against the State, it contributes to the heightening of bitter acrimonies and divisions among Nigerian people. For Obadiah Mailafia, ${ }^{27}$ the north and other regions may feel that a region that already enjoys such largesse is also the hub of criminal oil theft on such a staggering scale: 'To those who have, it seems, are granted opportunity to take even more through the backdoor' dovetailing into northern resistance and militancy in form of Boko Haram.

It has been convincingly argued that the Boko Haram militancy in the north eastern part of Nigeria, particularly in the old Kanem Bornu Empire, is an extension of the oil war in the Niger Delta. Adewale Maja-Pearce ${ }^{28}$ in the New York Times in Nigeria's Long Emergency, revealed how General Mohammed Buhari correctly captured the state of affairs that Niger Delta militants 'were given money and a training scheme was introduced for their members' while in contrast, 'when Boko Haram emerged, members of the sect were killed'.

Obadiah $^{29}$ therefore canvassed rightly that when we accept criminality as part of the natural order of things, we create an atmosphere where lawlessness becomes the accepted norm. The death of public reason often presages the death of the rule of law, which in turn paves way for the death of free republics. Christina Katsouris and Aaron Sayne of Chatham House (London Royal Institute of International Affairs), also reached the same conclusion that corruption and fraud are rampant in the oil sector. A dynamic, overcrowded political economy drives

\footnotetext{
${ }^{24} \mathrm{Id}$

${ }^{25}$ Daniel Soni, Why Niger Delta oil theft can't stop - Boyloaf. www.vanguardngr.com. September 7, 2013.

${ }^{26}$ Olayinka Collins, Nigeria is oil-dependent, not oil-rich, says Asobie. www.ngrguardiannews. October 16, 2013.

${ }^{27}$ Obadiah Mailafia, Nigeria's oil pillage crisis. http://businessdayonline.com. September 30, 2013.

${ }^{28}$ Adewale Maja-Pearce, Nigeria's long emergency, http://mobile.nytimes.com. September 22, 2013.

${ }^{29}$ Obadiah Mailafia, Loc. Cit.
} 
ISSN: 2689-5102

Volume 4, Issue 1, 2021 (pp. 85-101)

competition for looted resources. Poor governance has encouraged violent impunity and opportunism around oil and opened doors for organized crime. ${ }^{30}$

Debunking the Ebikabowei Boyloaf thesis further, Nasir El-Rufai ${ }^{31}$ canvassed that virtually everyone in Nigeria is taking the law into his hands because the state has failed to establish the rule of law and practice its tenets. He raised the question: While we respect the rights of all citizens including militants to demand for better governance and their rights to fight to protect the environment from the predatory activities of multinational oil companies, should we condone brazen theft, criminality and violence while rewarding the conduct with cash handouts? The obvious response is in the negative. Any state that chooses to reward bad behaviour or buy off those that take up arms against it with a blank cheque book should expect to see more and more of its citizens queuing up.

\section{Collateral Damage of Oil Theft}

Starting in October 2012, Nigeria experienced a large spike in piracy off its coast. By early 2013 it became the second most pirated nation in Africa next to Somalia with MEND (Movement for the Emancipation of the Niger Delta) being fingered. Since October 2012, it has hijacked 12 ships, kidnapped 33 sailors and killed 4 oil workers. ${ }^{32}$ Ex-Governor Dickson ${ }^{33}$ of Bayelsa State observed that perpetrators of illegal bunkering, sea piracy and pipeline vandalism act with impunity to undermine constituted authority: 'What is happening is more of a threat to national security than loss of revenue...the violence, brigandage and criminality that we experience in the Delta... have their roots in the creeks.'

'It is from the creeks they have the easy funds to recruit followers; it is from these activities of crude theft and illegal refining that people are able to sustain such a large number of youths following recruitment into cult groups.' But hard times await them, according to the Flag Officer Commanding the Central Naval Command of the Nigerian Navy, ${ }^{34}$ in that efforts are being made to reach out to the coastal communities where crime and criminalities are being perpetrated in the form of crude theft, illegal bunkering, illegal oil refineries, oil pipeline vandalism, piracy and sea robbery, among others.

But the militants are not taking the state-centric security apparatuses lying low. According to Ojakorotu Victor, who urged for dialogue instead of threats on the part of the state-centric security arsenal, the proliferation of arms encourages oil theft leading to 150,000 barrels of oil being stolen daily since 2008 by militants and their foreign collaborators. From 2008 to 2009, 33 Joint Military Task force (JTF) personnel have been killed, 38 missing, 55 wounded, 5 military gunboats destroyed, 3 seized and 24 automatic weapons as well as 579 rounds of

\footnotetext{
${ }^{30}$ Chatham House, Nigeria oil theft a global criminal enterprise. http://pmnewsnigeria.com. September 19, 2013.

${ }^{31}$ Nasir Ahmad El-Rufai, Impunity, injustice and insecurity: What is the role of Law? http://premiumtimesng.com. May 23, 2013.

32 Conflict in the Niger Delta. http://en.m.wikipedia.org/wiki.

${ }^{33}$ Ese Samuel, Illegal bunkering cause of arms build up, says Dickson. www.businessdayonline.com. July 9, 2013.

${ }^{34}$ Ebenezer Adurokiya, Hard time awaits criminal on Niger Delta waterways - Naval Boss. www.tribune.com.ng. October 12, 2013.
} 
ISSN: 2689-5102

Volume 4, Issue 1, 2021 (pp. 85-101)

ammunition captured. Militants have attempted to shoot down a naval helicopter and an Airforce helicopter, and 11 soldiers have been killed. ${ }^{35}$

On the other hand, the military task force of more than 6,102 soldiers and police deployed in 2012 to the Delta consisting of about 70,000 sq. kilometers, to curb oil theft and protect facilities, destroyed 1,819 makeshift or artisanal or illegal refineries, set ablaze 861 boats carrying as much as 20,000 liters each of illegally refined crude and destroyed 51 tanker trucks. ${ }^{36}$ Earlier, the task force had put into complete extinction not fewer than 218 illegal refineries in the creeks, stating: 'All the apparatus used to perpetrate these illegalities were destroyed while about 151 surface tanks and oil pumps were also destroyed'. It also destroyed 159 wooden cotonou boats each of which had 20,000 liters capacity, along with 27 barges used to convey illegal stolen crude oil to illegal refineries. The task force recovered 37 detonators used to burst pipes, gigantic hoses, generators, pumping machines and gas cylinders. The raids were around Oporoza village, Escravos in Delta, Alakri Waterside and the adjoining creeks of Sombreiro River at Abonema in Rivers State. ${ }^{37}$

Again, in 2013, the Nigerian Navy destroyed over 50 illegal refineries in the deep mangrove swamp near Otumara community in the Warri South West Council Area of Delta State. The site was the largest collection of illegal refineries so far in Delta State, with equipment and refined products worth billions of naira, and the act was a major breakthrough in the war against oil theft and illegal refinery operators. The illegal refinery-with a complex of connecting hoses leading to different local export terminals - was located inside a very narrow windy creek stretching several kilometers from the refining point. ${ }^{38}$ Above all, the JTF claimed that it destroyed over 6,000 illegal refineries in $2011 .{ }^{39}$

\section{Theft and Aging Infrastructure Debate}

Bunkering, which is another word for oil theft, is the highly dangerous and illegal practice of people breaking into pipes in order to tap some of the oil to sell in the black market. Shell and Eni, the two major multinationals with the most on-the-ground coverage attribute most of the spills in the country to bunkering. Environmental activists on the other hand argue that the aging oil facilities are more to blame. In fact, Amnesty International and Friends of the Earth International filed an official complaint against Shell before OECD (Organization for Economic Cooperation and Development) for breaches of the basic standards for responsible business, in that Shell uses misleading and discredited information totally lacking in credibility to blame majority of its oil pollution on sabotage to the tune of $98 \%$. This is with the underlying legal implication that under the Nigerian law, when spills are classified as being the result of sabotage, Shell has no liability with respect to compensation for damage done to people or their livelihoods. ${ }^{40}$ The pipelines are as old as the oil operations that began more than 50 years ago, and many are on the surface and under pressure 24 hours a day carrying oil for the past 50

\footnotetext{
${ }^{35}$ Ojakorotu Victor, Military and oil violence in Niger Delta. Journal of Energy Security. www.ensec.org. August 27, 2009.

${ }^{36}$ Flash: Pollution escalates in Niger Delta as military set ablaze 1,819 illegal refineries, 861 boats carrying crude, 51 tanker trucks. http://newsbytesnow.com. August 16, 2013.

${ }^{37}$ Adeola Yusuf, JTF destroys largest illegal refineries' site in Niger Delta. http://dailyindependentnig.com. May 7, 2013.

${ }^{38}$ Editorial, Illegal refineries in Niger Delta. www.ngrguardiannews. February 3, 2012.

${ }^{39}$ Id

${ }^{40}$ Shell accused over misleading figures on Nigeria oil spills. www.amnesty.org/en/news. January 25, 2011.
} 
ISSN: 2689-5102

Volume 4, Issue 1, 2021 (pp. 85-101)

years. The companies have only recently started to do replacements of their corroded pipes. In other words, it is a notorious fact that a lot of the infrastructure is aging and was built above ground, thereby making it easier for criminal elements to break the pipelines and carry out illegal activities. ${ }^{41}$

Sabotage and theft through siphoning have become a major issue as well as contributing to environmental degradation. Damaged lines may go unnoticed for days, weeks, months or years, and repair of damaged pipes takes even longer time. Oil siphoning has become a big business with the stolen oil quickly making its way into the black market. While the popularity of selling stolen oil is increasing, the number of deaths associated with it is also increasing. In late December 2006, more than 200 people were killed in Lagos due to pipeline explosion. ${ }^{42}$ Experts have also urged the Federal Government to take positive steps to revive and maintain the ailing and dilapidated refineries, and push for an enabling environment to encourage investors to build new refineries in Nigeria. ${ }^{43}$

For Abiye Membere, ${ }^{44}$ the land, air and waters of the Delta have been polluted and poisoned over many decades. And for this, the international oil companies must take a greater share of the responsibility even though they are not the sole cause. Sabotage, theft and illegal refineries also seriously share in the blame. But corrosion, outdated piping and maintenance malpractice by some of these large corporations has led to hundreds of small and large scale spills over the years. For instance, the Trans Niger Pipeline which transports around 150,000 bpd of crude oil from wells across the Niger Delta, through the creeks and impoverished villages of Ogoniland and Ogu-Bolo to the giant oil terminal at Bonny, is rusting away nearly 50 years old and known to spring leaks and spills. And it is, according to John Vidal, ${ }^{45}$ one of the most sabotaged lines in the world, with local communities accused by Shell of making over 20 attempts to tap oil from it in 2012 alone.

The environmental loss to illegal oil bunkering in Nigeria is estimated at \$1 trillion. Crude oil theft and illegal artisanal refining are widespread and they stifle traditional community life; they have outstripped fishing and farming as contributors to community Gross Domestic Product, and they are damaging and supplanting legitimate economic activities of the communities. By some estimates, the loss is almost 400,000 barrels per day. But oil theft invariably entails the destruction of pipelines and once detected would mean the closure of the pipelines to effect repairs, which cost a lot of time, money, energy, and man hours and power. The vicious circle of vandalism, detection, repairs and back to vandalism is what results in the estimated losses, part of which would be the actual stolen crude. ${ }^{46}$

\footnotetext{
${ }^{41}$ Nigeria: Poor oil spill clean-up methods affect Niger Delta communities. http://m.irinnew.org/report. February 7, 2008.

${ }^{42}$ Olayinka Collins, South-South Governors lead campaign for passage of PIB. www.ngrguardiannews

${ }^{43}$ Environmental issues in the Niger Delta, Academic Journals (Retrieved: May 21, 2007). http://en.m.wikipedia.org/wiki. October 3, 2013.

44 Abiye Membere, Time for change: New opportunities, partnerships and our energy future. www.vanguardngr.com. August 12, 2013.

45 John Vidal, F1bn a month: The spiraling cost of oil theft in Nigeria. www.theguardian.com. October 5, 2013.

${ }^{46}$ Oil theft in Niger Delta doesn't explain all the spills. www.legaloil.com. http://livewire.amnesty.org/2013/09/24. September 24, 2013.
} 
ISSN: 2689-5102

Volume 4, Issue 1, 2021 (pp. 85-101)

\section{Ideological Narratives}

On the whole, the scourge of oil theft has also transformed the narrative on environmental pollution in the delta. Currently, as revealed from the foregoing, two competing narratives have developed, each driven by the two ideologically opposed actors in the oil theft and illegal refining debate. The first narrative is that of the corporate state complex and the second is the critical narrative subscribed to by non-governmental organizations and rights activists. The first narrative holds with caution the view that oil theft is the dominant cause of pollution and environmental degradation while the second narrative subscribes to the tenacious view that weak regulation, aged infrastructure and lack of transparency on the part of the corporate state complex are responsible. ${ }^{47}$

Corporations hold tenaciously to the argument against oil theft because it has two legal defensive advantages. Apart from using it as a bulwark to explain away their inability to implement remediation due to the added argument of community blockade and militant resistance, it also enables the corporations to absolve themselves from criminal and civil liabilities. There is always therefore the blame game that goes on since oil theft has acquired a certain degree of notoriety in the delta. Oil theft therefore seems to be a very strong alibi for the corporations because of these two views. It is very likely that large scale theft committed by corporate state complex insiders are less likely to give rise to large scale environmental impact in that experts are involved, than small scale theft involving militants and communities in which there is a lesser likelihood of managing the process of siphoning in order to reduce the environmental impact. But worst of all is sabotage which is ab initio targeted at the struggle for regional justice, and therefore immoderate and uninformed by any economic calculation and consideration rather than wanton damage. While sabotage may lead to large scale spill, theft may not. ${ }^{48}$

But determining the extent to which oil theft, sabotage, weak regulation and infrastructure influence environmental degradation, according to Amnesty International, requires full transparency on the part of the corporations and the state, not campaign and propaganda machineries spewing out bloated and conflicting estimates and data. ${ }^{49}$ It also requires the full appreciation by the state and the industry of the fundamental needs and rights of the indigenous people to participate in their economy, and not necessarily the use of military forces against militancy and incipient show of rights of inclusion, claim of right and self-determination in theft, as it is elementary that two wrongs cannot make a right.

\section{Regularity of Theft Occurrence}

Multinational oil companies and the Federal government seem to be losing the battle to the perpetrators of the illegal trade of vandalism and oil theft, and the perpetrators are not perturbed by the various efforts being put in place to curb the menace. Amongst others, Shell attributed decline in its earnings in 2013 to rising cost and a surge in oil theft making it to sell four oil blocks. ${ }^{50}$ The four blocks are sitting in the heart of the eastern Niger Delta, an area particularly hit by crude oil theft. Shell is also selling the Nembe Creek Trunk Line, a key oil transport

\footnotetext{
${ }^{47}$ Id.

${ }^{48} \mathrm{Id}$.

${ }^{49}$ Okere Roseline, Counting the cost of pipeline vandalism. www.ngrguardiannews August 14, 2013.

${ }^{50}$ Editor, Shell consortium to sell 4 oil blocks in Nigeria. http://businessdayonline.com. October 11, 2013
} 
ISSN: 2689-5102

Volume 4, Issue 1, 2021 (pp. 85-101)

artery which had to be shut repeatedly after attacks by thieves. The asset sales represent a dramatic retreat by international oil and gas majors from the core of Nigeria's oil industry. All the four blocks and the Nembe Creek Trunk Line feed the Bonny Terminal, Nigeria's oldest export facility commissioned by Shell in $1961 .{ }^{51}$

Points of occurrence of pipeline tapping in Nigeria are mind-boggling. The vigilance of all Nigerians is necessary to check illegal oil bunkering, which has drastically reduced the socioeconomic potentials of the nation. For instance, Shell had to shut down the Trans Niger Pipeline following reports of new leaks 10 days after the line was repaired. The company claimed that a total of 189 crude theft points had been repaired on the 24 inch and 28 inch Trans Niger Pipeline between January and September 2013. Shell stated that it was 'dealing with a social tragedy, an environmental crisis and a sad waste of resources.' It found it difficult to safely operate its pipelines without having to shut them frequently to prevent leaks from illegal connections impacting the environment. And ironically, the thieves use Shell's repair windows to prepare and launch fresh illegal connections when it restarts production. ${ }^{52}$ The Trans Niger Pipeline has been repeatedly targeted and closed down five times since early July 2013 due to multiple leaks from crude theft. ${ }^{53}$

In fact, the Trans Niger Pipeline case is notorious. Company contractors were repairing one section of the pipeline when an explosion occurred and the official investigation team believed that the accident followed a botched attempt to steal tens of thousands of barrels of crude oil. Even as one group of engineers was removing illegal taps on the line, another group was installing equipment to allow huge amounts of oil to be siphoned straight into large barges where it would be taken to sea to waiting tankers bound for Europe and the US. ${ }^{54}$ Nigerian Agip Oil Company (NAOC) on the other hand lost 20,000 bpd to alleged crude theft in the Niger Delta region, leading to shutdown of production in early 2013 to effect repairs on 162 vandalized points caused by crude oil thieves. ${ }^{55}$

To Andrew Yakubu of Nigerian National Petroleum Corporation (NNPC), ${ }^{56}$ the corporation had over 774 break points since August 2012 from Atlas Cove to Ilorin. It recorded 181 break points between Atlas Cove and Mosimi depot and from Mosimi to Ibadan, it had 421 ruptured points. From Mosimi to Ore, it recorded 50 vandalized points and between Ibadan and Ilorin, it had 122 break points. Vandalism of the vast artery of pipelines led to trucking, and trucking has its attendant cost of maintaining a massive fleet of over 1,212 trucks for bridging into the hinterlands. According to Gbenga Komolafe of NNPC and PPMC, Nigeria lost about N163 billion from crude oil and petroleum products pipelines from 2009 to 2012 alone, not including associated costs - economic sabotage, environmental degradation and destruction of national

\footnotetext{
5151. Agencies, Shell raises alarm over crude oil theft in Nigeria. www.globaltimes.cn/com. October 11, 2013.

5252. Sulaimon Salau, Nigeria's oil production unsteady amid crude theft vandalism. www.ngrguardiannews.com. September 25, 2013. 5353. Id.

${ }^{5454}$. Oyadongha Samuel, Governor's forum set to check oil theft, says Uduaghan. www.vanguardngr.com. August 13, 2013.

${ }^{5555}$. Okere Roseline, Counting the cost of pipeline vandalism. www.ngrguardiannews August 14, 2013. 5656. Id.
} 
assets. ${ }^{57}$ Data available from NNPC further revealed that 53 break points were discovered along the $97 \mathrm{~km}$ Nembe-Creek Trunk line in the first quarter of 2013. ${ }^{58}$

The vandals operate with sophisticated equipment to carry out their criminal activities and have associations which organize activities and remit bribe money to security personnel that they regard as threats to their operations. They have several ruptured points which they seal off immediately after siphoning fuel. Ferdinand Esiegwu of Nigerian Security and Civil Defence Corps (NSCDC) claimed that in six months, 13 tankers were burnt on the directive and supervision of the government, and a total of 24 different cases with 37 suspects unlawfully dealing with petroleum products were also recorded in Edo State Command alone. ${ }^{59}$

The regularity is such that the state has formed the opinion that the country may not survive from the setback caused by the current vandalism of oil and gas installations in the next 20 years, yielding grounds to the suggestion that there is lack of political will from the state in dealing with the incidence which requires the severest punishment. ${ }^{60}$

\section{Contracting Security to Oil Thieves?}

For Alohan Juliet, ${ }^{61}$ several attempts have been made by the state to tackle the challenge of oil theft but not too much avail. The collaboration between NNPC and other international agencies, maritime operation committee of Army, Air-force, Navy, Customs, Police, SSS and the judiciary has not done much good in confronting the open secret that Nigeria-according to the Economic Magazine of August 4, 2012 - is the world's capital of oil theft. ${ }^{62}$ Even the juicy pipeline protection contract which the Wall Street Journal ${ }^{63}$ claimed was awarded to Mujaheed Asari Dokubo $(\$ 9 \mathrm{~m})$, Ebikabowei Boyloaf $(\$ 3.8 \mathrm{~m})$, Ateke Tom $(\$ 3.8 \mathrm{~m})$, and Tompolo Ekpemupolo $(\$ 22.9 \mathrm{~m})$ and all ex-militants, equally ended up as yet another drain on the pipelines.

It has been established that the heightened attacks on the pipelines coincided with the ongoing negotiation between the Federal Government and some of the ex-militants for the renewal of the pipelines surveillance contracts, amidst pressure from other militants to be factored into the deal. In fact, the revocation of the oil pipeline protection contracts, which were awarded to former agitators, is one of the factors responsible for the rise of oil bunkering in the Niger Delta in that it has forced the natives to resort to other jobs in a bid to survive, and the next phase of the crisis may be worse than the previous one if the state fails to implement the terms of the amnesty to the letter. This led Governor Oshiomhole of Edo State to express the concern that no nation should live with this kind of situation in which the state surrenders its national assets to thieves.

\footnotetext{
5757. Id.

${ }^{58}$ Alohan Juliet, Crude oil theft: Act of terrorism or lack of political will? www.legaloil.com. November 10, 2013.

${ }^{59}$ Minister of Petroleum, Allison Madueke, Id.

${ }^{60}$ Alohan Juliet, Loc. Cit.

${ }^{61}$ Alohan Juliet, Loc. Cit.

${ }^{62}$ Igwe Uche, Oil theft: What Nigeria must do. www.legaloil.com. July 10, 2013.

${ }^{63}$ Adeniyi Olusegun, Oshiomhole, Massive oil theft inexcusable. www.legaloil.com. July 14, 2013.
} 
The concept of individual contracting instead of communally based contract has also been attacked. Mittee Ledum argues that instead of giving the contracts to guard pipelines to an individual, the community should be given so that the youths of the community would be employed even on shift basis. Oil experts have equally assailed the ex-militants as incompetent, and that the manner in which the contracts were handed over to the ex-militants under the table rather than above the table, sends the wrong signals to the international community over the state's commitment to the principles of the Extractive Industry Transparency Initiative of which the state has given an affirmative action.

However, the Presidency came up stoutly through Kingsley Kuku in defense of the award of the contracts, insisting that the choice of ex-militants such as Tompolo, Ateke, Boyloaf and Dokubo was to ensure the success of the jobs as only the natives of the Niger delta were well placed and positioned to assist security agencies in combating oil theft and tampering with the oil facilities. In respect of the provision of the amnesty deal, the state argued that an appreciable means of livelihood for the ex-militants was needed to encourage them to prevail on their supporters to keep the peace. ${ }^{64}$

Boyloaf argued that only the few local players who are unwilling to play along with the security agencies are often arrested and paraded as thieves, while those who comply with the conditions imposed by the security agencies are often freed, and $75 \%$ of the stolen oil belongs to the security agencies.

\section{The Guardian Prescriptions}

It is not only that the 'blowing up of things' is causing more pollution and collateral damage as contended by some stakeholders, the debate is strife that the multinational oil companies are behind the military in stifling the growth of an indigenous industrial technology. The Guardian $^{65}$ submitted that makeshift refining implicates the ingenuity of the average Nigerian. That ingenuity exists in several areas of our national life and is often killed at its embryonic stage. In countries where foresight is brought to bear on the development process, such ingenuity constitutes the building blocks of technological breakthroughs.

Instead of simply criminalizing these outfits to the rebound of the major business interests of the multinationals, the Guardian ${ }^{66}$ further argued that the government ought to have found ways to help them structure and achieve transformation. Besides, they ought to be licensed and structured into efficient production units underlined by quality control. The existence of illegal refineries ought to be seen as a manifestation, not necessarily of criminal intent, but of survival initiatives that ought not to be suppressed. Rather, such initiatives ought to be harnessed within the ambits of the law as necessity is the mother of invention.

Two reactions to the editorial views of the Guardian ${ }^{67}$ were positive and apt: 'I think these men are heroes who refine oil illegally. What they need is funds to refine on a bigger scale and in a safer way. No mention was made of the quality of their products and how to improve on them. Release them and equip them.' 'Please help these...improve their business and stop harassing

\footnotetext{
${ }^{64}$ Ahamefula Ogbu, Nigeria: Oil theft - We are yet to catch the big thieves, says Mittee. http://m.allafrica.com/stories. October 14, 2013.

${ }^{65} \mathrm{Id}$.

${ }^{66} \mathrm{Id}$.

${ }^{67} \mathrm{Id}$.
} 
them. Help them with capital and technological empowerment to do their business. I salute their creativity, they just need help and support from the government that is just stealing their money.'

To the Guardian, ${ }^{68}$ solving the problem of unemployment entails creating opportunities and encouraging independent initiatives of the people. There is no doubt that illegal refineries provide employment for some people in areas ironically reputed for their poverty rather than opulence, and this is despite decades of oil exploitation. Therefore, a creative transformation of the makeshift refineries could provide further employment for the people and redirect their energies from social vices to productive initiatives.

The paper ${ }^{69}$ laments that it is shameful that the deficit in the industry occupies the front burner of national discourse, not for reasons of celebrating major strides, but for wrong reasons of continuing incompetence and sleaze. The defunct Biafra Republic refined petrol during the civil war over four decades ago, yet in the 21st century, the Federal Republic of Nigeria has not come of age either in local technology for the running of the industry or in the ability to sustain the imported technology upon which the industry is dependent.

A government commissioned report found that oil theft and illegal refining of oil have become widespread to the extent of stifling traditional life of oil-producing communities and turning them into ganglands. According to Kuku, 'Many vulnerable and impressionable young people now aspire to join this growing but extremely dangerous and certainly illegal and immoral business. $^{70}$ In fact, unemployment among the people of Niger Delta, is so high that it leads in part to the formation of militias and gangs that run illegal oil refineries found predominantly around the multinational company's main pipelines, in such a way that illegal extraction of oil is the only option open to earn a living. ${ }^{71}$

\section{CONCLUSION}

The fact that oil theft and illegal refineries in the Niger Delta have assumed an industrial and international dimension is no longer debatable. The damages which have resulted are equally enormous on all the stakeholders. It appears equally clear that the military option of suppressing the activities of the refiners have not helped matters. While it may seem abnormal to allow the theft and refining to grow and fester to the detriment of the state and the industry, legal control of the same may seem a better approach as that will yield a win-win situation.

The general disconnect between the implementation of recommendations of government panels and committees on the oil and gas sector has been revealed in this paper. While the Idika Kalu Special Task Force may have recommended the deregulation of the oil and gas sector of the Nigerian economy and particularly the privatization of the refineries, the State does not seem to be ready to carry out such a recommendation. Rather, it appears to be digging in and engaging the militants and natives accused of oil theft in the security of the critical assets. The

\footnotetext{
${ }^{68} \mathrm{Id}$.

${ }^{69} \mathrm{Id}$.

${ }^{70}$ Duru Emeka Alex, Addressing oil theft, illegal bunkering in Niger Delta. http://dailyindependentnig.com. August 26, 2013.

${ }^{71}$ Counting the costs of the Niger Delta's broken oil industry. http://theworldoutline.com. September 23, 2013.
} 
African Journal of Law, Political Research and Administration

ISSN: 2689-5102

Volume 4, Issue 1, 2021 (pp. 85-101)

www.abjournals.org

posture of the State has failed to send the right signal to private interests in the downstream sector of the industry and this does not seem to have the potential for encouraging indigenous technology transfer.

\section{RECOMMENDATIONS}

The government should have the traction to abide by and carry out the recommendations of committees it has set up to look into critical problems affecting the economy, instead of sweeping the recommendations under the carpet and continuing to take steps that are not in the interest of the economy in the long run. The debate for deregulation has gone full circle and the implementation appears to be the better way out of the scourge of oil theft and its associated crimes.

The Nigerian state should review its current laws against local oil refineries in the creeks and put in place liberal legal regimes that would accommodate and regulate the existence of illegal refineries. They (illegal refineries) seem to be one of the ways out of the technological issues calling for attention in the Nigerian oil and gas economy; that is, the development and advancement of the technology beneath indigenous oil refineries and its potential to create jobs and connect the two economies.

\section{REFERENCES}

[1] Adeola Yusuf, JTF destroys largest illegal refineries' site in Niger Delta. http://dailyindependentnig.com. May 7, 2013.

[2] Adewale Maja-Pearce, Nigeria's long emergency, http://mobile.nytimes.com. September 22, 2013.

[3] Ahamefula Ogbu, Nigeria: Oil theft - We are yet to catch the big thieves, says Mittee. http://m.allafrica.com/stories. October 14, 2013.

[4] Akinosho Toyin, The News Interview: Flawed Implementation of Amnesty Programme caused oil theft in the Niger Delta. http://mobile.saharareporters.com. April 15, 2013.

[5] Amaize Emma, Oyadonga Sam and Onoyume Jimitota, Oil: The conspiracy that robs Nigeria of billions of dollars. www.vanguardngr.com. August 25, 2013.

[6] Asu Femi, JTF discovers illegal crude loading points, impound barges. http://businessdayonline.com. July 4, 2013.

[7] Ayanruoh Felix, Nigeria - Cold facts of crude oil theft. www.vanguardngr.com. October 15, 2013.

[8] Chatham House, Nigeria oil theft a global criminal enterprise. http://pmnewsnigeria.com. September 19, 2013.

[9] Conflict in the Niger Delta. http://en.m.wikipedia.org/wiki. October 14, 2014

[10] Counting the costs of the Niger Delta's broken oil industry. http://theworldoutline.com. September 23, 2013.

[11] Daniel Soni, Why Niger Delta oil theft can't stop - Boyloaf. www.vanguardngr.com. September 7, 2013.

[12] Ebenezer Adurokiya, Hard time awaits criminal on Niger Delta waterways - Naval Boss. www.tribune.com.ng. 
African Journal of Law, Political Research and Administration

ISSN: 2689-5102

Volume 4, Issue 1, 2021 (pp. 85-101)

[13] Ebiri Kevin, How bunkering puts Nigeria's oil export in jeopardy. www.ngrguardiannews. September 29, 2013.

[14] Editorial, Illegal refineries in Niger Delta. www.ngrguardiannews. February 3, 2012.

[15] Ese Samuel, Illegal bunkering cause of arms build up, says Dickson. July 9, 2013.

[16] Flash: Pollution escalates in Niger Delta as military set ablaze 1,819 illegal refineries, 861 boats carrying crude, 51 tanker trucks. http://newsbytesnow.com. August 16, 2013.

[17] Duru Emeka Alex, Addressing oil theft, illegal bunkering in Niger Delta. http://dailyindependentnig.com. August 26, 2013.

[18] John Vidal, Flbn a month: The spiraling cost of oil theft in Nigeria. www.theguardian.com. October 5, 2013.

[19] John Vidal, Niger Delta oil spill victims reject 'derisory' Shell compensation offer. www.theguradian.com . September 13, 2013.

[20] Lagos (AFP), Nigerian crude oil stolen on an industrial scale. www.vanguardngr.com. September 20, 2013.

[21] Nasir Ahmad El-Rufai, Impunity, injustice and insecurity: What is the role of Law? http://premiumtimesng.com. May 23, 2013.

[22] Obadiah Mailafia, Nigeria's oil pillage crisis. http://businessdayonline.com. September 30, 2013.

[23] Olayinka Collins, Nigeria is oil-dependent, not oil-rich, says Asobie. www.ngrguardiannews. October 16, 2013.

[24] Ojakorotu Victor, Military and oil violence in Niger Delta. Journal of Energy Security. www.ensec.org. August 27, 2009.

[25] Oyadongha Samuel, Grounded crude oil barge: Navy arrests tug boat, 6 suspects. www.vanguardngr.com. August 15, 2013.

[26] Abiye Membere, Time for change: New opportunities, partnerships and our energy future. www.vanguardngr.com. August 12, 2013.

[27] Adekunle Ojo, Replicating the gains of deregulation in petroleum sector (2). www.vanguardngr.com. January 1, 2012.

[28] Adeniyi Olusegun, Oshiomhole, Massive oil theft inexcusable. www.legaloil.com. July 14, 2013.

[29] Agencies, Shell raises alarm over crude oil theft in Nigeria. www.globaltimes.cn/com. October 11, 2013.

[30] Ahamefula Ogbu, Nigeria: Oil theft - We are yet to catch the big thieves, says Mittee. http://m.allafrica.com/stories. October 14, 2013.

[31] Alohan Juliet and Tsan Adesuwa, Tompolo, Ateke Tom's pipeline contracts against global practice - Experts. www.legaloil.com. July 3, 2013.

[32] Alohan Juliet, Crude oil theft: act of Terrorism or lack of political will? www.legaloil.com. November 10, 2013.

[33] Amanze-Nwachukwu Chika, FG may dump Bayelsa, Kogi Greenfield refinery projects as only Lagos viable. www.thisdaylive.com August 25, 2013.

[34] Audu Liberty Oseni, Sepecial Report: Crude refining in Niger Delta communities. www.westafricainsight.org . January, 2013.

[35] Daniel Soni, Militants' pipeline protection contract part of Amnesty deal - Presidency. www.legaloil.com. http://www.vanguardngr.com. July 17, 2013.

[36] Daniel Soni, Why Niger Delta oil theft can't stop - Boyloaf. www.vanguardngr.com. September 7, 2013. 
African Journal of Law, Political Research and Administration

ISSN: 2689-5102

Volume 4, Issue 1, 2021 (pp. 85-101)

www.abjournals.org

[37] Editor, Shell consortium to sell 4 oil blocks in Nigeria. http://businessdayonline.com. October 11, 2013.

[38] Environmental issues in the Niger Delta, Academic Journals (Retrieved: May 21, 2007). http://en.m.wikipedia.org/wiki. October 3, 2013.

[39] Essiet Daniel, How to make private refineries viable. www.thenationonlineng.net. December 12, 2011.

[40] Experts advocates speedy passage of Petroleum Industry Bill. www.ngrguardiannews. July 31, 2013.

[41] FG to approve licenses for private refineries says Jonathan. http://www.premiumtimesng.com.

[42] Igwe Uche, Oil theft: What Nigeria must do. www.legaloil.com. July 10, 2013.

[43] Ogbechie Gabriel, Subsidy probe spurs new downstream investments - Rain Oil CEO. http://mobile.punchng.com. August 1, 2013.

[44] Okere Roseline, Counting the cost of pipeline vandalism. www.ngrguardiannews August 14, 2013.

[45] John Vidal, F1bn a month: The spiraling cost of oil theft in Nigeria. www.theguardian.com. October 5, 2013.

[46] Jonathan, sell the refineries now. http://mobile.punchng.com. August 18, 2013.

[47] Nigeria: Poor oil spill clean-up methods affect Niger Delta communities. http://m.irinnew.org/report. February 7, 2008.

[48] Okere Roseline, Government loses $\$ 1$ trillion to illegal oil bunkering. www.ngrguardiannews. August 16, 2013.

[49] Okere Roseline, How investors stall government's drive for private refineries. www.ngrguardiannews.com. December 9, 2012.

[50] Okere Roseline, Why investors are shunning Nigeria's oil, gas sector. www.ngrguardiannews. September 9, 2013.

[51] Oil theft in Niger Delta doesn't explain all the spills. www.legaloil.com. http://livewire.amnesty.org/2013/09/24. September 24, 2013.

[52] Olayinka Collins, South-South Governors lead campaign for passage of PIB. www.ngrguardiannews.

[53] Oyadongha Samuel, Governor's forum set to check oil theft, says Uduaghan. www.vanguardngr.com. August 13, 2013.

[54] Sulaimon Salau, Nigeria's oil production unsteady amid crude theft vandalism. www.ngrguardiannews.com. September 25, 2013.

[55] Shell accused over misleading figures on Nigeria oil spills. www.amnesty.org/en/news. January 25, 2011.

[56] Six new refineries hurray! But not yet Uhuru. www.vanguardngr.com. July 9, 2012.

[57] Udo Bassey, Nigeria to integrate trained ex-militants into oil industry. www.legaloil.com. http://premiumtimesng.com/business/149388. November 11, 2013. 